\title{
National Stereotypes and Political Issues in Polnische Hochzeit (1937) by Joseph Beer
}

\author{
Ryszard Daniel Golianek \\ Univerza Adama Mickiewicza, Poznanj \\ Adam Mickiewicz University, Poznań
}

Within the opulent repertoire of German operetta, particularly in the interwar 1930 s times, an important place is occupied by works whose plot involves references to Polish themes, or those wherein Polish characters appear. 'The predominant - though not the only- method of presenting the Polish milieu is a confrontation with representatives of invading nations (Germany, Austria and Russia), and the differences in behaviour as well as personal qualities of the characters, resulting from such confrontations, frequently generate the main dramatic conflicts in operettas' plots. Both the manner in which protagonists are developed and their characteristics concurrently become manifestations of peculiar stereotypes of a particular nation, whereas moral assessments of a protagonist's behaviour often lead to overgeneralisations transferred onto communities, or even entire nations. $^{2}$

1 In order to simplify the discourse, I keep using the notion of 'German operetta' in the sense of operetta works in the German language, written in Germany, Austria and in the countries that were ruled and governed by them. In spite of a certain lack of precision, the term is applied in the subject literature, similarly to the names used for other vocal-instrumental works such as Italian and German opera in the works of Mozart, Haydn, etc.

2 The question of presence of Polish themes in operetta has already been mentioned by Oswald Panagl, who discusses, in a short article, issues related to four operettas: Der Bettelstudent (1882) by Carl Millöcker, Polenblut (1913) by Oskar Nedbal, Der letzte Walzer (1920) by Oscar Straus and Die blaue Mazur (1920) by Franz Lehár. See: Oswald Panagl, “'Solang's noch solche Frauen gibt, ist Polen nicht verloren'. Identitätskrisen und Solidaritätsstiftung auf der Operettenbühne." In Politische Mythen 
Polish motifs appear in a dozen operetta works, spanning the period of 50 years, from Der Bettelstudent by Carl Millöcker (1882) up to Die schöne Carlotti (1943) by Willy Czernik. What is striking about this abundant repertoire is first and foremost a tendency to treat Polish elements as carriers of exoticism, with a distinct Polish culture adding an attractive tone, colour and atmosphere to the course of dramatic events. ${ }^{3}$ Still, it is necessary to single out a group of a few operettas wherein social and cultural issues, shown against the Polish background, come into prominence in a particular way. Their authors did not limit themselves to showing Polish people as an exotic ethnic group, bringing in an appealing element of contrast to the main plot of the work, but they made an attempt to present essential political and cultural issues associated with this ethnic group in a more detailed manner. One must not forget the historical context, namely the circumstances and times when these works were composed. It is the year 1918 that seems to be an obvious turning point for the way in which Polish people were presented, the year of regaining independence by Poland after more than a hundred years of partitions and the absence of the country on the map of Europe. ${ }^{4}$

Polnische Hochzeit, composed in 1937 by Joseph Beer to the lyrics of Alfred Grünwald and Fritz Löhner-Beda, appears to be one of the most interesting exponents of this kind of repertoire. Beer (1908-1987), a Polish composer of Jewish descent, studied music first in his hometown of Lvov, and next in Vienna. His first success as a composer of stage musical works was the premiere of the operetta Der Prinz von Schiras, written together with Löhner-Beda in 1934. The operetta Polnische Hochzeit, the premiere of which took place in the Stadttheater in Zurich on 3 April 1937, was anoth-

und nationale Identitäten im (Musik-) Theater: Vorträge und Gespräche des Salzburger Symposions 2001, vol. 2, ed. Peter Csobádi et al. (Anif-Salzburg: Verlag Mueller-Speiser, 2003), 829-42. The title of the article was derived from the text Polenblut (No. 7, Marschlied: Brüder, ich bin verliebt).

3 Interest in the subject of the fates and customs of various nations' representatives seems to be typical of and frequently encountered in operetta works written in the first decades of the $20^{\text {th }}$ century. Derek B. Scott defines German operetta of this time as 'a cosmopolitan genre', drawing our attention both to diverse types of interests and topics, changes in operetta styles, as well as affiliation of the genre composers with the milieu of the Jewish Dispersion, which facilitated worldwide distribution of this repertoire. Derek B. Scott, "Early Twentieth-Century Operetta from German Stage: A Cosmopolitan Genre,” The Musical Quarterly 99, no. 2 (2016): 254-79. 
er outcome of the two authors' (and Alfred Grünwald's) collaboration. The work was a huge success, and before the outbreak of World War II it was presented on many European stages, including Vienna, Warsaw and Madrid.' After the war, Beer withdrew his earlier compositions, which resulted in the absence of Polnische Hochzeit in the repertoire of the second half of the $2 \mathrm{O}^{\text {th }}$ century. In 2011, the Viennese publisher Doblinger published the score of the work ${ }^{6}$ and this had an impact on a contemporary interest in the composition: in 2012, the first post-war performance of the work took place at the Wiener Operettensommer festival ${ }^{7}$, in 2016 there was a CD released by the CPO record company, ${ }^{8}$ and in the 2018/19 season there was the latest stage premiere of the work in the Graz Opera House.'

\section{Issues covered by the work}

The plot of Polnische Hochzeit takes place in the $19^{\text {th }}$ century, in the times when there was no Polish state on the maps of Europe since it had ceased to exist as a consequence of $18^{\text {th }}$-century partitions. The events of the operetta take place in a Polish manor house situated in the Russian partition, which constitutes an important element of the plot and generates an additional political conflict. ${ }^{10}$ The sentimental characteristics of the plot, essential in a work meant to be bourgeois entertainment with moralistic qualities, should be also confronted with various national concepts, since in

5 The Viennese premiere of the operetta, scheduled for 1938 (with Richard Tauber in the part of Boleslav), was cancelled by fascists due to political reasons. Cf. "Polnische Hochzeit," Opereten-Lexikon, http://www.operetten-lexikon.in$\mathrm{fo} /$ ?menu $=167$ \&lang $=1$. On 1 October 1939 , in turn, the French premiere, featuring Jan Kiepura and Marta Eggerth, was scheduled to take place in the Parisian Théâtre du Châtelet, which did not happen as a result of the World War II outbreak. Cf. Stefan Frey, "Joseph Beer - von den Nazis um den Erfolg gebracht," BR Klassik, December 11, 2015, https://www.br-klassik.de/themen/oper/polnische-hochzeit-esay-10o. html.

6 Joseph Beer, Polnische Hochzeit, Operette in drei Akten und einem Vorspiel [full score and piano score] (Wien: Doblinger 09064, 2011).

7 Direction: Marion Dimali, scenography: Markus Windberger, premiered on 19 July 2012.

8 Münchner Rundfunkorchester, conductor Ulf Schirmer, CPO 555 059-2, 2 CD, 2016.

9 Oper Graz, director Sebastian Ritschel, scenographer Martin Miotk, premiered on 8 December 2018, https://onlinemerker.com/wien-theresianum-polnische-hochzeit/.

10 This presentation of the plot of the Polnische Hochzeit operetta is based on the following edition of the libretto: Polnische Hochzeit, Operette in drei Akten (mit einem Vorspiel) von Alfred Grünwald und Dr. Fritz Löhner, Musik von Joseph Beer [libretto] (Wien: Wiener Operettenverlag, 1936). 
the operetta's dramaturgy there appear both Poles and citizens of the invading country - Russians. To present both the local and national colour, the Polish protagonists bear traditional Polish first names (Boleslav, Mietek, Staschek, Jadja) and stereotypical Polish surnames with the '-ski' ending (or '-ska' in a female version), such as Oginsky, Zagorski, Kawietzky, Schlapinska, Lombska, whereas the chief of the Russian police is called Sergius Korrosoff.

The operetta starts with an introduction (Vorspiel) on the Austrian-Russian border when the main character of the work, the 32-year-old count Boleslav Zagorski, is attempting to illegally cross it. He spent 16 years in exile in Austria, where he had fled together with his father, who had been persecuted for his patriotic activity in support of Poland. Now, Boleslav decides to return to Poland, by whatever means necessary, prompted by a longing for his home country and adolescent love, Jadja, a daughter of Baron Mietek Oginski. A Pole he meets in the border inn discovers the young man's identity and at the mention of his father he gives Boleslav a fake passport, thanks to which he manages to enter the territory of the Russian partition.

In the first act of the operetta, the main dramatic threads are outlined. Notorious for his love of gambling, Baron Mietek Oginski, Jadja's father, goes into heavy debt with his powerful and wealthy neighbour - Count Staschek Zagorski, Boleslav's uncle. Count Staschek, living quite a roguish life, has just divorced his fifth wife, and he has made the decision to marry Jadja. Mietek sees this marriage as a chance to be relieved of his debts, but Jadja does not agree to marry old and off-putting Staschek as she still hold the memory of her beloved Boleslav. Boleslav, in turn, spurred by his longing for Jadja, arrives at Oginski's property immediately after his return to the country and meets his love once again. He also intends to visit his uncle Staschek in order to get back the family treasures and money that was left behind by his father. Suza, the skilled housekeeper at Oginski's manor estate, warns Boleslav about Staschek and tells him not to reveal his true identity, as his uncle has become a traitor to the Polish nation, collaborating with the Russians.

Dressed up as a servant, Boleslav serves at the table during Staschek's visit to Mietek's house and - unrecognised by his uncle - learns to his horror from the conversation that Staschek not only does not intend to return the family treasures back, but he has also decided to send his nephew to Siberia immediately upon his arrival at the manor. The prospect of Staschek 
and Jadja's wedding then compels Boleslav to disclose his identity to his uncle. The sudden appearance of Korosoff, the tsarist secret police (ochrana) officer, changes Boleslav's situation: it turns out that his illegal crossing of the border with a fake passport has been discovered, and now he is a wanted man. Mietek does not reveal Boleslav's true identity but Staschek makes hiding the truth conditional on Jadja agreeing to marriage. Thus in order to save Boleslav, Jadja - terrified and blackmailed - agrees to marry Staschek. Staschek then bribes Korosoff and dismisses him, and seizing the opportunity also arranges with Mietek the date of the wedding.

The second act takes place in Mietek Oginski's manor house on the day of Staschek and Jadja's wedding. Suza has prepared a scheme: after the groom has arrived, guests will be welcomed with a wedding drink and then - taking advantage of the festivities - Jadja and Boleslav will run away and cross the nearby Russian-Austrian border and get married there, as Suza has already arranged appropriate documents with the starost, or mayor. A flare launched into the sky is to be a sign that the whole plan succeeded and the newlyweds were saved. Staschek's arrival triggers Suza's plan, with Staschek and Mietek drinking a lot, and fast, with the alcohol served to them by Casimir, Suza's lover. Since the wedding is just starting, Mietek demands that Staschek should give him back his bills of exchange. Having received the documents, he burns them in the fireplace, thus settling his debts, or so he imagines.

The wedding is supposed to be carried out in line with an old Polish tradition, according to which the bride should be dressed in an outfit that covers her completely and should be led by six bridesmaids to the chapel altar. Suddenly everybody notices a flare in the sky and Suza triumphantly announces that there will be no wedding, as the bride has just married Boleslav. Her joy, however, turns out to be premature. Staschek saw through Suza's scheme, sent some dragoons after the runaways and the flare simply means that Jadja has been caught. Now that nothing can prevent Staschek from marrying her, he also reveals shrewdness in his relations with Mietek: instead of giving him back the bills of exchange he had only handed over blank sheets of paper, and to prove this he shows genuine documents to his would-be father-in-law.

In the manor chapel a forced wedding ceremony thus takes place. Boleslav arrives and tells Casimir the story of Jadja being kidnapped by the dragoons. He wants to disrupt Jadja and Staschek's wedding but it is already too late - the newlyweds are leaving the chapel. Staschek finally gives 
Mietek back the real bills of exchange and he immediately destroys them. When the groom demands a kiss from the bride, the bridesmaids take off her veil and it turns out that the person he married was not Jadja but Suza. Staschek, deceived, faints, as does Casimir - terrified by Suza's action and her betrayal.

A short Act III takes place in the manor house belonging to Count Staschek Zagorski. Suza explains to the heartbroken Casimir that she decided to take such a step in order to save Jadja. The marriage between Suza and Staschek turns into a farce - Suza behaves in a hysterical manner, constantly wants presents from Staschek, teases him and keeps sulking. She believes that such conduct will provoke Staschek to ask for a rapid divorce that will be carried out on her terms. After Mietek has dissuaded Staschek from establishing Suza's fault in court, explaining the difficulties involved, the disappointed groom has nothing else to do but humbly ask Suza for a divorce. Staschek agrees to all her conditions, including reconciliation with his nephew and paying him back all the money he had stolen, and signs divorce documents. Everybody leaves, Staschek is left alone with his dog and decides to lead a solitary life.

\section{National stereotypes in the operetta's plot}

The very title of the operetta, Polish Wedding, implies a tradition of lavish celebrations on the territory of Poland. According to various accounts, wedding parties and feasts of many days were, for centuries, a trademark of the aristocracy in Poland; the remnants of this culture, in a rather less imposing manner, can still be observed in Poles' behaviour today. Information on the course of this multi-day wedding party appears on numerous occasions in the text, e.g. in the finale of first act: "Drei Tage wird getanzt und getrunken" (For three days there will be dances and binge drinking). The plot also presents the custom of six bridesmaids leading the bride to the altar, though certain details of this practice are modified to fit Suza's scheme. What is also noteworthy is the attention given to a realistic depiction of the manner in which the Poles feast, with the foods and drinks described, such as the wedding punch (Hochzeitpunsch). In different parts of the plot, and in stage directions, one can also find details of the characters' national costumes: "in der Tracht eines schmucken polnischen Bauern" (in the outfit of an elegant Polish peasant), "Boleslav trägt einfaches Nationalkostüm" (Bole- 
slav is dressed in a simple national costume), "Nationalkostüm mit Degen" (a national costume with a sabre). ${ }^{\text {II }}$

A more thorough analysis of the libretto reveals a series of allusions to Polish tradition and culture, showing in-depth knowledge of the national background. It seems that it was Beer himself who contributed to this, as he grew up in Poland and among Polish people. In the context of an operetta in the German language, such a situation is rather exceptional, as in a number of other works with Polish themes there are just broad stereotypes of Poland and Poles. In Polnische Hochzeit such elements are also found, though they are not used simply to add a superficial, attractive local colour, but also present an actual picture of Polish culture in the interwar period.

The most potent allusions to Polish realities can be noticed in the language used by the characters. In the context of a light-hearted intrigue, what draws our attention is a comment in the stage directions on Mietek Oginski's way of speaking: "he speaks with a slight Polish accent" ("spricht mit leichtem polnischen Akzent"), which introduces a comic element but also presents the character's ethnic background to German-speaking audiences. Moreover, phrases and words in Polish are used over the course of the operetta on numerous occasions, and contribute to the local colour with expressions such as "Schlachzizen" [noble men], "Der Pan" [Sir], "Der Starost" [the Starost]. They clearly accompany the character of Boleslav, especially when he gives in to emotion upon his return home, singing in the mazurka rhythm about beloved homeland and addressing it in his native Polish language [Table 1].

The feeling of happiness from Boleslav's song is a result of both his joy at returning home and rapture over the beauty and temperament of Polish girls. The list of female names given by Boleslav in the last verse of the song is a very good example of how a realistic approach in an operetta is combined with literary fiction and national stereotypes. Most of the names are derived from Polish tradition and are actually used in reality either in their official (Maria) or diminutive versions (Halka, Kasia, Stasia, Mania). Still, some of them, like Talka, Stania or Karia, are used very rarely, are colloquial and their introduction in this context should be assumed as a successful example of linguistic stylisation, as well as due to the use of a list in

11 For a very well-documented study on the development of images and stereotypes of Polish people in the eyes of Germans see: Hubert Orłowski, Polnische Wirtschaft: zum deutschen Polendiskurs der Neuzeit (Wiesbaden: Harrasowitz Verlag, 1996). 
Table I: Joseph Beer, Polnische Hochzeit, Act I, no. 4, the scene of Boleslav's arrival Polnische Hochzeit [libretto], 20-I.

\section{Polska! Polska!}

Alles, was wir lieben, liegt in diesem Wort!

Polska! Polska!

Laßt die alten Lieder klingen!

Polenland, mein Heimatland!

Jetzt bin ich wieder dein!

Was auch immer sei,

Einmal wirst du frei!

Polenland, mein Heimatland!

Jetzt bin ich wieder dein!

Herrlich ist's, daheim zu sein!

Wo solche Blumen blüh'n,

die schönsten Frau'n,

Wohin die Augen seh'n

Flammenheiße Blicke glüh'n;

Die Polin ist so schön!

Polenland, mein Heimatland!

Jetzt bin ich wieder dein!

Herrlich ist's, daheim zu sein!

Halka! Talka!

Kommt, ihr drallen Mädel,

alle kommt zu mir!

Kasja, Stasja,

Laßt uns sie Mazurka tanzen.

Manja, Stanja,

heute sind wir lustig, heute tanzen wir!

Karja, Marja!

Kommt, wir woll'n Mazurka tanzen.

\section{Poland! Poland!}

All we love is in this word!

Poland! Poland!

Let old songs sound!

The land of Poles, my homeland!

I am yours again!

As it has always been,

you will be free now!

The land of Poles, my homeland!

I am yours again!

It is great to be back home again!

Where such flowers bloom,

The most beautiful women,

Wherever you take a look,

Ardent looks are burning.

A Polish woman is so beautiful!

The land of Poles, my homeland!

I am yours again!

It is great to be back home again!

Halka! Talka!

Come, girls in bloom,

Come all to me!

Kasia, Stasia

Let's dance mazurka.

Mania, Stania

Today we are merry, today we're dancing!

Karia, Maria!

Come, let's dance mazurka.

the song. What should also be noted is the fact that some of the main characters' names are also diminutive forms (Mietek=Mieczysław, Staschek$=$ Stanisław, Jadja $=$ Jadwiga, Suza $=$ Zuzanna $)$.

The national stereotype of Poles as a nation eagerly reaching for alcohol is explicitly presented in the cartoonish characteristics of Count Staschek, who gladly enumerates various kinds of alcohol bearing typically Polish names. In the Polnische Hochzeit's plot, they are pronounced in Germanised and inaccurate versions, but even a Polish listener can effortlessly recognise their native prototypes, e.g. Borowitschka (borovička, a widespread spirit in Slovakia, a type of gin) or Jerczebinka (rowanberry spirit, berry brandy). As an appetizer served with alcohol, Staschek orders "Flatschki" (chitterlings), a hot, typically Polish meat dish. Standard toasts in the Polish language - "Niech żyje!" [Long live!] or "Na strowje" (in a phonetic version, correctly: "Na zdrowie!" [Cheers!]) complement this 
tendency to faithfully reflect Polish realities, similarly to the swear words shouted out by Staschek many times: "Do stai djablow!" (correctly: "Do stu diabłów!" [What the hell!]), or "Psiakrew!" [Damn it!].

The characters of Count Staschek Zagorski and Baron Mietek Oginski, representatives of an older generation of Poles, are primarily characterised in accordance with depictions of the Polish aristocracy from the pre-partition period, so they represent relatively anachronistic and stereotypical images of Poles-Sarmatians. Meetings of the two characters and their conversations take place in each act of the operetta, and it can be assumed that this is the result of a desire to present more in-depth and blunter Polish characteristics in the work. During these conversations both men tell various witty anecdotes and make use of proverbs, although it is hard to identify and recognise them as truly Polish characteristics. Some of these proverbs, for example, function both in German- and Polish-speaking circles: "Aber wer zuletzt lacht, lacht am besten" (He laughs best who laughs last), "Bleibt doch alles in der Familie" (Everything runs in the family), other ones seem to be too strongly rooted in the German language structure in terms of rhythm and rhyme to regard them as translations of Polish sayings, e.g. "Beim Kartenspiel und Hochzeitmachen kann man erst am Nachhausweg lachen!" (One can enjoy a game of cards and participation in wedding only on the way home), "Nur ein verdammt mißtrauisches Luder traut nicht dem Schwager und nicht dem Bruder" (Only a pathetic and suspicious scum does not trust their brother-in-law or brother), or "Polnische Freundschaft ist doppelte Freundschaft" (Polish friendship is double friendship). In fact, in general these sayings are unknown in both Poland and Germany.

\section{Polish musical elements}

What plays an important role for the formation of national values in the structure of the operetta are musical categories associated with Polish characteristics. Typically, elements of national culture, mainly national dances - mazur (mazurka), krakowiak and polonaise, are used to characterise Polish protagonists and related events on stage. Undoubtedly, the presence of these idiosyncratically Polish musical qualities created much of the operetta's attractiveness and its colour, but also - to some extent - it might have contributed to authentication of the presented national issues.

The mazurka (an international term for the Polish dance mazur) is the most frequently applied reference to the sphere of folk dances, present both in dance sections (e.g. in Act I) and in vocal parts, e.g. in Boleslav's aria 
Polska! Polska! or in Staschek's song Die verflixten Weiber, one of the operetta's main hits, which returns as a recapitulation at the end of the work. The krakowiak, a dance from southern Poland whose name is associated with the city of Krakow, can be, in turn, linked to the plot's setting - the border areas of Russian and Austrian partitions, which can be quite precisely established and located on the map. The runaway couple (Jadja and Boleslav) were supposed to get married in nearby Jarosław, out of reach of the Russian secret police. Jarosław is a Polish town situated between Krakow and Lvov, located within the Austrian territory before World War I, and the maps from this period show that the frontier between Austria and Russia was demarcated near Jarosław. The krakowiak appears in the plot as early as the beginning of Act I, as one of the first manifestations of local colour, in Suza and Casimir's duet written in the rhythm of a krakowiak (Du hast rote Backen, No. 3). This presentation of the dance, as well as other manifestations over the course of the work, contains all the rhythmic-metrical features of the krakowiak, including the characteristic syncopated element.

The presence of the polonaise, in turn, whose name unambiguously indicates a Polish background, has been reserved for the beginning of Act II (No. 9 Polonaise und Chor). The solemn character of this dance, additionally highlighted with the sound of trumpets and percussion instruments, corresponds well with the wedding ceremony that takes place in the second act of the operetta. What is also important is the text of this polonaise, performed by a chorus of wedding guests: "Noch ist Polen nicht verloren, heißt's im alten Heimatlied" (Poland has not perished yet, as an old patriotic song said). This is a quote from the lyrics of Mazurek Dąbrowskiego, a patriotic song "Poland has not perished yet" in a commonly known German translation. The song, associated with the activity of Polish Legions in Italy (at the turn of $18^{\text {th }}$ and $19^{\text {th }}$ centuries) under the command of Jan Henryk Dąbrowski, obtained the status of the Polish national anthem in 1927 (i.e. ten years before the premiere of Polnische Hochzeit), a status it still retains. The lyrics of Mazurek Daprowskiego, cited here out of the musical quotation context, play the role of a recollection of Polish tradition, and the character of these national issues becomes combined with the situation depicted in the operetta [Table 2].

A particularly interesting episode in the operetta, abundant in allusions to Polish music culture, is the finale of Act II, when an attractive and elaborate wedding ceremony takes place. In the musical layer there appear quotations from popular songs, still strongly rooted in Polish culture: " $O$ 
Table 2: Joseph Beer, Polnische Hochzeit, act II, No. 9, Polonaise und Chor Polnische Hochzeit [libretto], 39.

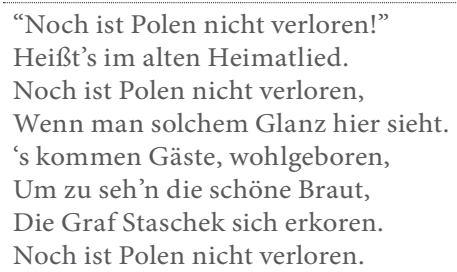

\author{
'Poland has not perished yet!' \\ This is what an old patriotic song said. \\ Poland has not perished yet. \\ When one can see such lavishness here. \\ Guests of noble birth come, \\ To see a beautiful bride \\ Chosen by count Staschek for himself. \\ Poland has not perished yet.
}

mój rozmarynie" (with the text "Jetzt nach alter Sitte") or "Umarł Maciek, umart" maintaining the mazurka rhythms (in the form of a dance with a drone accompaniment) and "Jeszcze jeden mazur dzisiaj" (in a more modern, slightly jazzy arrangement). There is also a stylisation of a short folk song (a female chorus "Schön wie der junge Frühling") and Jadja's dumka "Leise kling dein Lied". Over the course of wedding events, Staschek orders everybody to dance one more Polish dance, the kujawiak, of a more tranquil and sentimental character: "Tanzt uns jetzt den Kujawiak, so tanzt man in Polen" (Dance the kujawiak now the way it is danced in Poland), which leads to a spectacular ballet scene.

All these national musical characteristics make the Polnische Hochzeit score unusually strongly marked with Polish elements. Compared to other German operettas related to Polish tradition, this work differs considerably in its wealth of references to authentic Polish musical culture, going beyond the trivial, stereotypical identification of the Polish musical style with obvious mazurka rhythms and polonaises. There is no doubt that the composer's deep relation with Polish music culture arose from the fact that he grew up in Poland, and was a Polish citizen very familiar with the national music culture. Thanks to this, when speaking of Polnische Hochzeit one can say it is a successful synthesis of the Austrian operetta style with elements of Polish colour, reflected in the issues covered in the work as well as its musical characteristics.

\section{Political issues}

In the plot of Polnische Hochzeit one can observe obvious references to political issues. The principal conflict behind the operetta's plot - rivalry between an uncle and his nephew for Jadja's hand - overlaps with deeper questions of a political and moral nature. Uncle Staschek, who is strongly connected with the Russian annexation of Poland, calls for help the tsa- 
rist ochrana [secret police] and does not hesitate to make use of his political connections in order to pursue his cynical plans. Staschek's overt collaboration with the Russian annexation and his close contacts with Korosoff, the chief of the secret police, introduce a serious element of treason against the nation. The idea of employing the thread of collaboration with the Russian authorities links Beer's operetta with one of the most important $19^{\text {th }}$-century operatic works in Poland, Straszny dwór [The Haunted Manor] by Stanisław Moniuszko, where alleged treason against the nation becomes a crucial part of the plot. ${ }^{\mathrm{I2}}$ Saturated with national content, the plot of Polnische Hochzeit is one of many clear manifestations of the work's political implications and Staschek's connection with the annexationist regime, introduced to the libretto, not only determined the change of this character into a villain but also had an impact on the more serious material nature of the composition. The hero of the opera, Staschek's nephew Boleslav Zagorski, gains this status and that of a patriot when he arrives from the Austrian partition to the Polish territory (in the Russian partition) under a false name, thus risking his life for his nation. This serious patriotic-national element makes Polnische Hochzeit very different from a typical operetta, the plots of which primarily oscillate around romantic and social relations.

Tension between Poles and Russians, as well as the domination of the Russian occupying force, are additionally heightened by the constant introduction of political issues to the operetta's plot. In the libretto there are many allusions to Russian culture - such as Russian currency ("Rubel", "Kopeke"), and apart from ochrana there also appear Cossack troops. Encroaching in the rhythm of a march, military policemen cry out the words praising the tsar in the finale of Act I ("Es lebe der Zar!" - "Long live the tsar!") and Staschek threatens Boleslav, from time to time, by saying that he will be sent to Siberia. Listeners who are more familiar with Russian culture and musical tradition will easily recognise in the musical layer subtle references to the works of Modest Mussorgsky, who often stylised Russian folk music, which are introduced by Beer at the very beginning of the operetta, in the introduction (Vorspiel). Such elements of stylisation or palimpsest in Polnische Hochzeit not only play the role of making the composition's musical fabric more attractive, but also carry an evident political message: rec-

12 Straszny dwór (1864) by Stanisław Moniuszko is one of the most important works of Polish national opera, a composition treated in the times of partitions as a manifestation of Polishness and a stronghold of patriotic ideals. See: Rüdiger Ritter, Der Tröster der Nation: Stanisław Moniuszko (1819-1872) und seine Musik (Wiesbaden: Otto Harrassowitz, 2019). 
ognisable elements of Russian musical traditions make it possible to evocatively emphasise the annexation context and visualise the setting of the operetta's plot in the Russian partition.

Undoubtedly, a political undertone is also introduced to the libretto's text with a quote from Schiller's Ode to Joy: "Seid umschlungen Millionen! Diesen Kuß der ganzen Welt!" (Be embraced, Millions! This kiss to all the world!). It is articulated by Boleslav in Act III when he is finally able to unite with Jadja. And even though Jadja's answer "Gib ihn lieber mir!" (You'd better give it [the kiss] to me!) places Schiller's solemn tone into a melodramatic context, it is actually a subtle allusion to the Enlightenment and libertarian ideological slogans that clearly sounds in the lines articulated by Boleslav, a passionate lover and ardent patriot. The idea of introducing intertextual allusions, in any case, seems to be a consistent narrative and expressive element applied in the work. As regards the characteristics of Boleslav, this element occurs for the first time at the end of the finale of Act I - after the scene wherein Jadja agrees to marry Staschek to save Boleslav, the latter sings solo, heartbroken after losing his love and embittered as he looks forward to a tragic future. In the music of this scene, the composer makes an allusion to (or even uses a quote from) Cavaradossi's aria from Act III of Giacomo Puccini's Tosca, sung by this character just before his execution. Shared aspects of both heroes' (Boleslav and Cavaradossi) characteristics include an exposure to danger and the uncertainty of their fates, as well as their involvement in independence movements. Beer thus stresses this aspect, introducing a reference to commonly known music by Puccini and trusting that the audience would likely connect the situational context pertaining to both characters.

Considering the crucial role of national-political issues in the operetta's plot, it would make sense to reflect upon the social undertone and patriotic message of Polnische Hochzeit. In the context of the operetta's plot, the title is ambiguous, indicating not only national Polish wedding customs but also an additional factor: the scheme prepared by Suza. Staschek's humiliation can be interpreted in this context as a punishment for his collaboration with the Russians, and the Polish character of his wedding, indicated in the title, should be treated as a form of stereotypical belief in Poles' patriotism and dominance of the national mindset over the sphere of personal life. ${ }^{13}$ From this perspective, all the musical elements typical of the then

13 Political and national issues in the operettas exploring Polish themes are noticed by Oswald Panagl, who treats this type of problems as typical of this current in German 
operetta traditions (hit songs, elements of dance and popular culture, jazz, etc.) should be treated only as an attractive background, applied to present much more serious ideological and political issues.

\section{Bibliography}

Beer, Joseph. Polnische Hochzeit, Operette in drei Akten (mit einem Vorspiel) von Alfred Grünwald und Dr. Fritz Löhner, Musik von Joseph Beer [libretto]. Wien: Wiener Operettenverlag, 1936.

Beer, Joseph. Polnische Hochzeit, Operette in drei Akten und einem Vorspiel [full score and piano score]. Wien: Doblinger 09064, 2011.

Beer, Joseph. Polnische Hochzeit, Operette in drei Akten und einem Vorspiel, Münchner Rundfunkorchester, conductor Ulf Schirmer, CPO 555 059-2, $2 \mathrm{CD}, 2016$.

Davies, Norman. God's Playground. A History of Poland, Vol. II: 1795 to the Present. Oxford: Clarendon Press, 1981.

Frey, Stefan. "Joseph Beer - von den Nazis um den Erfolg gebracht.” BR Klassik, December 11, 2015. https://www.br-klassik.de/themen/oper/polnische-hochzeit-esay-10o.html.

Orłowski, Hubert. Polnische Wirtschaft: zum deutschen Polendiskurs der Neuzeit. Wiesbaden: Harrasowitz Verlag, 1996.

Panagl, Oswald. "Solang's noch solche Frauen gibt, ist Polen nicht verloren.' Identitätskrisen und Solidaritätsstiftung auf der Operettenbühne.” In Politische Mythen und nationale Identitäten im (Musik-) Theater: Vorträge und Gespräche des Salzburger Symposions 2001, vol. 2, edited by Peter Csobádi et al., 829-42. Anif-Salzburg: Verlag Mueller-Speiser, 2003.

"Polnische Hochzeit." Opereten-Lexikon. http://www.operetten-lexikon. info/?menu=167\&lang $=1$.

Ritter, Rüdiger. Der Tröster der Nation: Stanisław Moniuszko (1819 -1872) und seine Musik. Wiesbaden: Otto Harrassowitz, 2019.

Scott, Derek B. "Early Twentieth-Century Operetta from German Stage: A Cosmopolitan Genre.” The Musical Quarterly 99, no. 2 (2016): 254-79.

operetta works: "Im goldenen wie im silbernen Segment der österreichischen Operette lässt sich eine Nische ausmachen, die man als polnisches Genre bezeichnen könnte. Denn abseits aller zeitlichen und stilistischen Unterschiede und zusätzlich zum gemeinsamen Schauplatz gibt es einige durchgehende Merkmale: nationaler Stolz der Protagonisten, Widerstand gegen Fremdbestimmung, politischer Zusammenhalt in schwierigen Zeiten, schließlich - der Gattung gemäß - ein guter Ausgang, der zumeist privates Glück und öffentliche Wohlfahrt auf einen Nenner bringt." Panagl, "Solang's noch solche Frauen gibt," 839. 